\title{
FAKTOR YANG BERHUBUNGAN DALAM DOKUMENTASI KEPERAWATAN
}

\author{
Dwi Syafriningsih/dwisyafriningsih@gmail.com
}

Latar Belakang

Dokumentasi merupakan suatu catatan penting yang dapat dijadikan sebagai bukti dalam permasalahan hukum. Dokumentasi keperawatan merupakan bukti dari pencatatan dan pelaporan perawat, dalam melakukan dokumentasi perawat dan tim kesehatan lainnya dalam memberikan pelayanan kesehatan dengan cara komunikasi yang akurat dan baik secara tertulis dengan tanggung jawab perawat (Hidayat, 2007).

Dokumentasi keperawatan tidak hanya menggambarkan kualitas perawatan saja tetapi membuktikan pertanggung jawaban dari setiap tim keperawatan (Potter \& Perry, 2005).

Maka dari itu, jika kegiatan keperawatan ini tidak didokumentasikan dengan baik, akurat, obyektif,dan lengkap serta sesuai dengan standar asuhan keperawatan maka sulit untuk membuktikan bahwa tindakan keperawatan telah dilakukan dengan benar (Gillies, 2000; Carpenito, 1999).
Keberhasilan pendokumentasian sangat dipengaruhi oleh seorang perawat sebagai ujung tombak dalam memberikan asuhan keperawatan (Potter \& Perry, 2005). Menurut Gibson (1996) dalam Suratun (2008) bahwa faktor individu yang memengaruhi perilaku kerja antara lain umur, lama kerja, pendidikan, dan pelatihan. Produktivitas seorang perawat menurun ketika bertambahnya umur, sedangkan lama kerja mempunyai hubungan yang positif terhadap produktivitas pekerjaan. Siagian (2002) menyatakan bahwa makin tinggi tingkat pendidikan seseorang maka semakin besar keinginan untuk memanfaatkan pengetahuan dan keterampilan yang dipunya. Pelatihan merupakan bagian dari proses pendidikan untuk meningkatkan dan meluaskan pengetahuan dan keterampilan seseorang (Notoatmodjo, 2003)

Pendokumentasian yang berkualitas mempunyai ciri-ciri yaitu berdasarkan fakta, data yang akurat, kelengkapan, ringkas, terorganisasi, ketepatan waktu, mudah untuk dibaca. 


\section{Metode}

Metode dalam penulisan ini menggunakan metode kualitatif, yaitu merupakan metode yang sifatnya memberikan suatu penjelasan dengan analisis. Metode ini bersifat subjektif, yaitu proses penelitian yang lebih fokus pada landasan teori. Metode yang digunakan dalam kajian ini adalah Literature review.

Metode ini menganalisis, eksplorasi dan kajian bebas pada artikel, jurnal, maupun ebook yang releven dan berfokus pada metode pembelajaran yang mempengaruhi kemampuan mahasiswa agar mampu dalam melakukan pendokumentasian. Adapun artikel yang digunakan pada literature review ini adalah artikel yang didapatkan dengan memuat 3 database Pubmed, Geogle Scholar dan Science Direct.

\section{Hasil}

Berdasarkan hasil pencarian literature didapatkan bahwa banyak faktor yang dapat meningkatkan kemampuan mahasiswa untuk selalu melakukan pendokumentasian dalam keperawatan dalam melakukan tindakan.

Agung (2009) menyatakan bahwa pengetahuan sangat berperan penting dalam mengambil suatu tindakan. Pengetahuan menjadi latar belakang dalam menentukan beberapa pilihan tindakan yang mungkin dapat dilakukan, kemudian mengimplementasikan pilihan tersebut, sehingga pengetahuan mengenai dokumentasian asuhan keperawatan bagi seorang perawat sangatlah penting sebagai dasar pengambilan keputusan untuk melakukan pendokumentasian asuhan keperawatan dengan baik dan benar.

Pendokumentasian yang tidak efisen dan tidak efektif akibat dari kualitas dan keakuratannya kurang memadai menyebabkan terjadinya kesalahan komunikasi antar perawat maupun profesi lain. Komisi keselamatan perawatan dan kualitas kesehatan Australia pada tahun 2008 mengidentifikasi 13\% dari kesalahan manajemen klinis berasal dari kesalahan dokumentasi (Siswanto, dkk 2013).

Dari penelitian beberapa literature, perawat yang berusia lebih dari 28 tahun melakukan pendokumentasian dengan lengkap sebesar $61,3 \%$ dibandingkan dengan perawat yang berusia kurang dari 28 tahun. Dan juga menunjukkan bahwa perawat yang berpendidikan DIII Keperawatan mendokumentasikan asuhan keperawatan lengkap sebesar $58,6 \%$ dibanding dengan SPK (36,4\%). Penelitian Nuryani (2014) menunjukan adanya hubungan antara pengetahuan dan sikap perawat terhadap 
kelengkapan pendokumentasian asuhan keperawatan dengan hasil yang dimana terdapat hubungan antara pengetahuan perawat dengan pendokumentasian asuhan keperawatan, sedangkan sikap tidak terdapat hubungan yang bermakna, hal ini membuktikan semakin tinggi pengetahuan dan sikap seorang perawat maka semakin meningkat juga kinerjanya dalam pendokumentasian asuhan keperawatan.

\section{Pembahasan}

Dokumentasi asuhan keperawatan merupakan proses pelaksanaan pencatatan asuhan keperawatan dimulai dari pengkajian saat pasien masuk sampai pasien dinyatakan sehat. Diagnosis yang diangkat berdasarkan masalah yang ditemukan, perencanaan keperawatan, tindakan yang dilakukan serta evaluasi dari proses asuhan keperawatan yang diberikan (Nursalam, 2007).

Dokumentasi asuhan keperawatan merupakan bagian dari asuhan keperawatan yang dilaksanakan sesuai standar, dengan pemahaman dan keterampilan dalam menerapkan standar yang baik merupakan suatu hal yang mutlak bagi setiap perawat agar mampu membuat dokumentasi keperawatan secara baik dan benar (Deden Dermawan, 2012).

Dokumentasi merupakan suatu informasi lengkap meliputi status kesehatan pasien, kebutuhan pasien, kegiatan asuhan keperawatan, serta respon pasien terhadap suatu asuhan yang diterimanya. Dengan demikian, dokumentasi keperawatan mempunyai bagian yang besar dari catatan klinis pasien yang menginformasikan faktor tertentu atau situasi yang terjadi selama asuhan dilakukan. Selain itu catatan juga merupakan suatu cara untuk komunikasi dan koordinasi antar profesi, yang dapat dipergunakan untuk mengungkapkan suatu fakta aktual untuk dipertanggung jawabkan. Keberadaan dokumentasi baik berbentuk catatan maupun laporan akan sangat membantu komunikasi antara sesama perawat maupun tenaga medis lainnya dalam rencana pengobatan dan penyembuhan pasien (Setiadi, 2012).

Penelitian Nuryani (2014) menunjukan bahwa dengan adanya hubungan antara pengetahuan dan sikap perawat terhadap kelengkapan pendokumentasian asuhan keperawatan terdapat hubungan yang bermakna antara pengetahuan perawat dengan pendokumentasian asuhan keperawatan. Hal ini membuktikan semakin tinggi pengetahuan dan sikap seorang perawat maka semakin meningkat juga kinerjanya dalam pendokumentasian asuhan keperawatan. 
Dalam pelaksanaan dokumentasi asuhan keperawatan sangat dipengaruhi oleh perilaku perawat itu sendiri, dimana perilaku dipengaruhi oleh tiga faktor yaitu faktor predisposing yang terwujud dalam pengetahuan, sikap, keperacayaan, keyakinan, nilai-nilai.

\section{Faktor-Faktor dalam pendokumentasian keperawatan}

\section{Usia}

Dari penelitian beberapa literature atau jurnal perawat yang berusia lebih dari 28 tahun melakukan pendokumentasian dengan lengkap sebesar $61,3 \%$ dibandingkan dengan perawat yang berusia kurang dari 28 tahun. Hal ini memperlihatkan bahwa hubungan antara umur dan kinerja merupakan isu penting, karena terdapat keyakinan bahwa kinerja akan menurun dengan bertambahnya umur (Robbin, 2006). Penelitian ini didukung pendapat Gibson (1996) dalam Suratun (2008) yang mengemukakan bahwa pekerja yang lebih tua dianggap lebih tanggap secara teknis, lebih banyak pengalaman dan lebih bijaksana dalam pengambilan keputusan.

\section{Tingkat Pendidikan}

Hal ini sesuai dengan pendapat Gibson (1996) dalam Suratun (2008) yang mengemukakan bahwa tingkat pendidikan yang tinggi umumnya menyebabkan seseorang lebih mampu dan bersedia menerima tanggung jawab. Sedangkan Siagian (2002) menjelaskan bahwa makin tinggi pendidikan seseorang makin besar keinginan untuk memanfaatkan pengetahuan dan keterampilan. Penelitian ini didukung pula oleh penelitian Fizran dan Mamdy (2002) yang mendapatkan bahwa tingkat pendidikan berhubungan dengan kinerja perawat dalam melakukan pendokumentasian keperawatan serta penelitian Usman dan Tafal (2002) yang mengemukakan bahwa tingkat pendidikan berhubungan dengan motivasi perawat dalam penerapan proses keperawatan.

\section{Lama Kerja}

Hasil penelitian dari beberapa literature didapatkan bahwa perawat yang bekerja lebih dari 10 Tahun melakukan pendokumentasian keperawatan dengan lengkap sebesar $60,0 \%$. Hal ini sesuai dengan pendapat Robbins (2006) dalam Suratun (2008) yang menyatakan terdapat suatu hubungan yang positif antara masa kerja dan produktifitas pekerjaan. Makin lama seseorang bekerja makin terampil dan berpengalaman melaksanakan pekerjaannya. Lama kerja menjadi sangat penting karena 
dapat mencerminkan tingkat kepuasan akhir yang dapat dicapai oleh karyawan. Hal ini didukung oleh penelitian Hotnida dan Sumiatun (2002) yaitu faktor lama kerja berpengaruh terhadap kinerja perawat dalam pendokumentasian proses keperawatan.

\section{Pelatihan}

Hasil penelitian dari beberapa literature didapatkan bahwa perawat yang pernah mengikuti pelatihan akan melengkapi dokumentasi keperawatannya sebesar 59,3\% dibandingkan dengan perawat yang tidak pernah mengikuti pelatihan asuhan keperawatan. Penelitian ini sesuai dengan pendapat Notoatmodjo (2003) yang menyatakan bahwa pelatihan merupakan bagian dari proses pendidikan untuk peningkatan pengetahuan dan keterampilan kerja. Hal ini didukung oleh penelitian Fizran dan Mamdy (2002) yang mendapatkan bahwa pelatihan berhubungan dengan kinerja perawat dalam pendokumentasian keperawatan dan penelitian Soetisno dan Christophora (2000) yang menunjukkan bahwa ada pengaruh positif dari pelatihan pada kelengkapan dokumentasi keperawatan.

\section{Pengetahuan terkait Dokumentasi Keperawatan.}

Hasil penelitian dari beberapa literature menunjukkan bahwa perawat yang pengetahuannya terkait dokumentasi keperawatan rendah, ada sejumlah 58,3\% yang dokumentasi keperawatannya lengkap. Sedangkan perawat yang memiliki pengetahuan dokumentasi keperawatan tinggi, ada sebanyak 56,2\% yang dokumentasi keperawatannya lengkap. Hal ini bertentangan dengan penelitian Fizran dan Mamdy (2002) yang mendapatkan bahwa tingkat pengetahuan berhubungan dengan kinerja perawat dalam pendokumentasian keperawatan.

\section{Beban Kerja}

Hal tersebut dikarenakan banyaknya jenis pekerjaan yang harus diselesaikan oleh tenaga kesehatan yang profesional dalam waktu satu tahun dalam satu sarana pelayanan kesehatan (DepKes, 2004). Beban kerja merupakan suatu kondisi dimana para pekerja merasa terbebani, baik secara fisik maupun non fisik dalam pekerjaan. Kondisi tersebut dapat diperberat oleh kondisi lingkungan yang tidak mendukung secara fisik atau non fisik (DepKes, 2007).

Beban kerja sangat mempengaruhi mutu perawat dalam mendokumentasikan asuhan keperawatan. Perawat akan lebih tergesa - 
gesa dalam melakukan proses pendokumentasian dan lupa dalam mendokumentasikan sehingga kelengkapan pendokumentasian tidak terpenuhi (Andri, Indra, \& Susmarini, 2015).

Penelitian juga menyebutkan bahwa beban kerja juga menunjukkan mayoritas beban kerja perawat adalah dalam kategori berat. Pendokumentasian asuhan keperawatan yang tidak lengkap paling banyak terdapat pada pengkajian. Peneliti berpendapat bahwa perawat tidak memiliki cukup waktu untuk melakukan pengkajian secara komperhensif yang dapat dikarenakan kurangnya waktu, banyak nya pekerjaan yang harus dikerjakan oleh perawat pada shift pagi dan sore hari.

Penelitian mengenai faktor-faktor yang berhubungan dengan kelengkapan dokumentasi keperawatan menunjukkan hasil bahwa lingkungan tempat kerja juga menjadi salah satu faktor yang memiliki hubungan dengan kelengkapan pendokumentasian asuhan keperawatan menjadi kurang baik(Noorkasiani, Gustina, \& Maryam, 2015).

Begitu pula dengan penelitian Kusumawaty dan Yani (2001) yang mendapatkan bahwa adanya hubungan yang berpola positif antara pemahaman terhadap pendokumentasian proses keperawatan dengan kompetensi mendokumentasikan proses keperawatan.

Dari implikasi model pada hasil didapatkan bahwa perawat yang memiliki sikap yang kurang vaik atau negati, perilakunya untuk melakukan pendokumentasian asuhan keperawatan kurang baik. Pengetahuan yang kurang pada perawat mempengaruhi pendokumentasian yang kurang. Insentif yang kurang berhubungan dengan pendokumentasian kurang. Beban kerja yang tidak sesuai berhubungan dengan pendokumentasian kurang. Karena itu disarankan supaya pendokumentasian dapat dilakukan dengan baik, maka diperlukan sikap positif. Agar sikap perawat positif diperlukan pengetahuan yang baik, insentif yang cukup dan beban kerja yang sesuai.

\section{Penutup}

\section{Kesimpulan}

Dokumentasi keperawatan sangat penting karna merupakan catatan kesehatan pasien yang dapat dijadikan sebagai bukti nyata mengenai status kesehatannya. Faktor yang berhubungan dengan dokumentasi keperawatan yaitu usia, tingkat pendidikan, lama kerja, pelatihan, pengetahuan terkait dokumentasi keperawatan, beban kerja. 


\section{Saran}

Mengingat pentingnya pendokumentasian keperawatan maka disarankan agar perawat memiliki pengetahuan dan keterampilan yang baik, karena dokumentasi keperawatan merupakan bagian penting dalam keperawatan.

\section{Daftar Pustaka}

Andri, F. Indra, R. Susmarini, D. (2015). MANUSKRIP ANALISIS FAKTORFAKTOR YANG MEMPENGARUHI PERAWAT DALAM MEMENUHI KELENGKAPAN DOKUMENTASI KEPERAWATAN DI IGD RUMAH SAKIT WILAYAH PONTIANAK KALIMANTAN BARAT. Jurnal Medika Respati. ISSN : 1907 - 3887. 10(4). 49-59.

Dewi, R. Maigeni. (2018). Lama masa kerja dan manajemen waktu dengan pelaksanaan dokumentasi asuhan keperawatan. REAL in Nursing Journal (RNJ). 1(1). 30-41.

Fitri. N.T. Korompis, G. E. C. Kaunang, W. P. J. (2019). FAKTOR-FAKTOR YANG BERHUBUNGAN DENGAN PENDOKUMENTASIAN ASUHAN KEPERAWATAN DI RUMAH SAKIT DAERAH KOTA TIDORE KEPULAUAN. Jurnal KESMAS. 8(3). 60-68.
Gunawan. (2016). FAKTOR-FAKTOR YANG MEMENGARUHI PENERIMAAN PERAWAT MELAKSANAKAN PENDOKUMENTASIAN ASUHAN KEPERAWATAN. Jurnal Pendidikan. l(10). 1926-1934.

Muryani. Pertiwiwati, E. Setiawan, H. (2019).

KUALITAS

PENDOKUMENTASIAN

ASUHAN

KEPERAWATAN DI RUANG RAWAT

INAP. Nerspedia. 2(1). 27-32.

Noorkasiani. Gustina, R. Maryam, S. (2015).

FAKTOR-FAKTOR YANG BERHUBUNGAN DENGAN KELENGKAPAN DOKUMENTASI KEPERAWATAN. Jurnal Keperawatan Indonesia. 18(1). 1-8.

Putra Aryata P.I. (2012). Analisis Penerapan Standar Asuhan Keperawatan di Ruang Rawat Inap Rumah Sakit Umum Provinsi Sulawesi Tenggara. Yogyakarta. UGM. Tesis Universitas Gajah Mada 2012.

Rohimah, Nikmatur. (2010). Integrasi proses keperawatan dalam pembelajaran klinik keperawatan. One to One teaching and feed Back. The Indonesia jurnal of Health Science, vol (1), No (1).

Simamora, R. (2009). Dokumentasi Proses Keperawatan. 
Simamora, R. H., Purba, J. M., Bukit, E. K., \& Nurbaiti, N. (2019). Penguatan Peran Perawat Dalam Pelaksanaan Asuhan Keperawatan Melalui Pelatihan Layanan Prima. JPPM (Jurnal Pengabdian Dan Pemberdayaan Masyarakat), 3(1), 25-31.

Wahyuni, E. D. Asmoro, C. P. Susiana, E. (2019). Faktor yang Berhubungan dengan Mutu Pendokumentasian Asuhan Keperawatan. FUNDAMENTAL AND MANAGEMENT NURSING JOURNAL. 2(1). 16-23.

Wulandini, P. S. Kriantob, T. Priwahyuni, P. (2016). FAKTOR-FAKTOR YANG BERHUBUNGAN DENGAN PENDOKUMENTASIAN ASUHAN KEPERAWATAN. NERS JURNAL KEPERAWATAN. 12(2). 131-142. 